\title{
Novel Exchangeable Effector Loci Associated with the Pseudomonas syringae hrp Pathogenicity Island: Evidence for Integron-Like Assembly from Transposed Gene Cassettes
}

\author{
James C. Charity, Kyong Pak, Charles F. Delwiche, and Steven W. Hutcheson \\ Department of Cell Biology and Molecular Genetics, University of Maryland, College Park, MD 20742, U.S.A.
}

Submitted 6 December 2002. Accepted 5 February 2003.

Pseudomonas syringae strains use a type III secretion system (TTSS) to translocate effector proteins that assist in the parasitism of host plant cells. Some genes for effector proteins are clustered in the exchangeable effector locus (EEL) associated with the hrp pathogenicity island. A polymerase chain reaction-based screen was developed to amplify the EEL from $P$. syringae strains. Of the 86 strains screened, the EEL was successfully amplified from 30 predominately North American P. syringae pv. syringae strains using $h r p K$ and $q u e A$-derived primers and from an additional three strains using $h r p L$ and queA-derived primers. Among the amplified EEL, ten distinct types of EEL were identified that could be classified into six families distinguishable by genetic composition, but other types of EEL may be present in strains isolated in other geographical regions. No linkage with the host range of the source strain was apparent. Gene cassettes carrying conserved flanking, coding, and intergenic sequences, present in different combinations, were identified in the characterized EEL. Six new alleles of known effectors were identified that differed from the homolog in sequence, size, or both of the gene. One of these apparently novel effector proteins, HopPsyB, retained a strongly conserved amino terminus similar to that of HopPsyA, but other regions of the two polypeptides were only weakly similar. hopPsyB was expressed from an apparent operon that included $h r p K$ and a shcA homolog, shcB. Escherichia coli MC4100 expressing the hrp TTSS, ShcB, and HopPsyB elicited the hypersensitive response (HR) in tobacco, consistent with effector production. Indicative of translocation as an effector, $P$. syringae pv. tomato DC3000 expressing a HopPsyB':'AvrRpt2 fusion elicited the HR in RPS2 ${ }^{+}$Arabidopsis thaliana. P. syringae pv. tomato DC3000 carrying HopPsyB exhibited slightly enhanced virulence in several Brassica spp. These results are consistent with the hypotheses that the EEL is a source of disparate effectors functioning in pathogenicity of $P$. syringae strains and that it evolved independently of the $h r p$ pathogenicity island central conserved region, most likely through integron-like assembly of transposed gene cassettes.

Corresponding author: S. W. Hutcheson: E-mail: sh53@umail.umd.edu; Telephone (301) 405 5498; Fax: (301) 3149489.

*The $\boldsymbol{e}$-Xtra logo stands for "electronic extra" and indicates the HTML abstract available on-line contains five supplemental figures not included in the print edition.
The pathogenicity of Pseudomonas syringae strains has been linked to activities encoded by the hrp pathogenicity island (PAI) (Alfano et al. 2000; Hutcheson 1999). This tripartite PAI is composed of an exchangeable effector locus (EEL), a conserved effector locus (CEL), and a central conserved region (CCR) (Alfano et al. 2000) that expresses the hrp-encoded type III secretion system (TTSS). The $h r p$-encoded TTSS is required for the translocation of effector proteins, known as Avr, Vir, or Hop proteins, into the cytoplasm of host plant cells (Gopalan et al. 1996; Leister et al. 1996; Mudgett and Staskawicz 1999; Pirhonen et al. 1996). In susceptible plants, the translocated effectors suppress or modify the cellular defense responses of the host (Chen et al. 2000) or alter the physiology of the host cell to favor growth of the pathogen (Dangl and Jones 2001; Hutcheson 2001). In resistant plants, one or more of the effectors elicit the programmed cell death associated with hypersensitive response (HR) (Dangl and Jones 2001; Hutcheson 2001). Translocated effectors are, therefore, essential for the virulence of the strains and control host range by initiating cellular defense responses in resistant plants. Since strains of $P$. syringae frequently have distinct host ranges, these strains likely differ in the effectors they translocate into host cells. Conversely, strains with similar host ranges are thought to retain a subset of translocated effectors that are necessary for virulence in a specific host. Therefore, to understand the pathogenicity and host range of a given $P$. syringae strain, it is important to identify the effectors that are expressed and translocated by that strain.

Several methods have been used to survey $P$. syringae strains for translocated effectors. Most $a v r$ genes have been identified by screening a genomic library of one strain for genes that affect the host range of another strain in a 'gene-forgene' manner (Leach and White 1996; Staskawicz et al. 1984; Vivian and Gibbon 1997). The analysis of the P. syringae pv. tomato DC3000 genome has revealed at least 51 candidate or known effector proteins (Collmer et al. 2002; Fouts et al. 2002; Petnicki-Ocweija et al. 2002), many of which share sequence similarity with effectors originally identified in other strains through phenotypic screens. In each case, these effectors appear either to be expressed from HrpL-dependent promoters (Fouts et al. 2002), to carry apparent TTSS secretion signals (Guttman and Greenberg 2001; Guttman et al. 2002; PetnickiOcweija et al. 2002), or both. Another approach has been to screen the genome of a strain for translocated proteins by using randomly generated fusions to an 'avrRpt2' cassette that requires TTSS-dependent translocation for activity in RPS2 lines of Arabidopsis thaliana (Guttman et al. 2002). In some cases, 
culture filtrates have been used to identify secreted proteins (Mudgett and Staskawicz 1999; van Dijk et al. 1999; Yuan and He 1996). Unfortunately, most $P$. syringae strains secrete TTSS effectors into liquid media at levels below the threshold of detection (Alfano and Collmer 1997; Hutcheson 1999; Li et al. 1992). The results of these screens indicate that effector genes can be dispersed throughout the genome (Kim et al. 1998), clustered in plasmid-borne 'pathogenicity islands' (Jackson et al. 1999), or associated with the hrp PAI in either the EEL or CEL (Alfano et al. 2000; Hutcheson 1999).

Although the effectors encoded by the EEL are unlikely to be solely responsible for a strain's host range, the EEL appears to be a highly variable source for effectors (Alfano et al. 2000; Hutcheson 1999). Each strain characterized thus far contains a distinct EEL that encodes at least one demonstrated effector (Alfano et al. 2000; Heu and Hutcheson 1993; Mansfield et al. 1994; Petnicki-Ocweija et al. 2002). In P. syringae pv. syringae 61, the EEL consists of hopPsyA (also known as hrmA), which encodes a known TTSS-dependent effector (Alfano et al. 1997; Heu and Hutcheson 1993), and shcA, producing a chaperone for HopPsyA (van Dijk et al. 2002). The EEL of P. syringae pv. syringae $\mathrm{B} 728 \mathrm{~A}$ includes six genes, previously named orfl through orf6, three of which encode potential translocated effectors (Alfano et al. 2000). P. syringae pv. syringae $\mathrm{B} 728 \mathrm{~A}$ HopPsyC product shares weak sequence similarity with AvrPphC; hopPsyE expresses a homolog of AvrPphE; and the HopPsyV product exhibits sequence similarity to AvrXct (Alfano et al. 2000). The P. syringae pv. tomato DC3000 EEL consists of five genes previously designated orfl through orf5 that share little sequence similarity with the genes of the $P$. syringae $\mathrm{pv}$. syringae 61 or $P$. syringae pv. syringae B728A EEL (Alfano et al. 2000). orfl of the P. syringae pv. tomato DC3000 EEL encodes the effector HopPtoB (Fouts et al. 2002; PetnickiOcweija et al. 2002). The functions of the other genes in the $P$. syringae pv. tomato DC3000 EEL have not been reported.

During a promoter trap screen used to isolate HrpL-dependent promoters from $P$. syringae strains (Hutcheson et al. 2003),

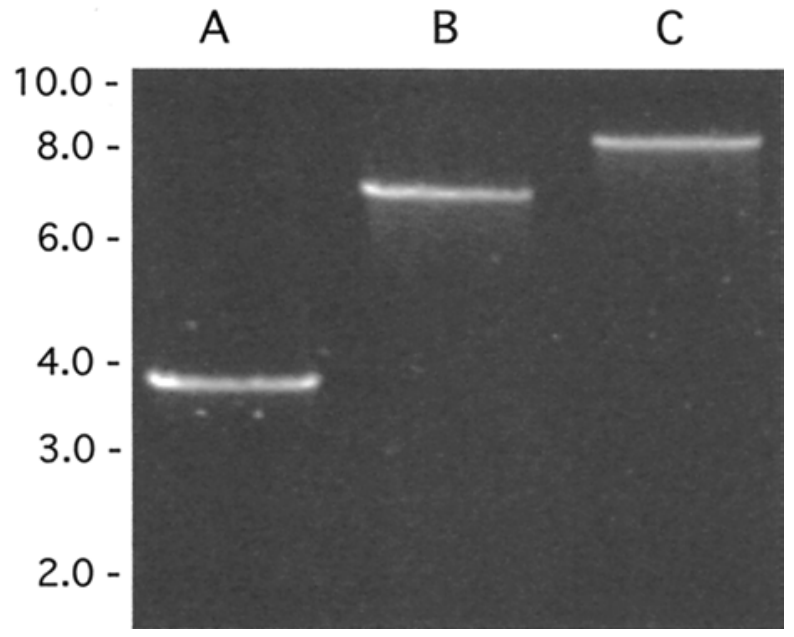

Fig. 1. The exchangeable effector locus (EEL) amplified from Pseudomonas syringae strains. Polymerase chain reaction amplification of the EEL from A, $P$. syringae pv. syringae $61 \mathbf{B}, P$. syringae pv. tomato DC3000, and C, P. syringae pv. syringae B728A employed primers Q920 and K2648 and ProofPro polymerase. Whole cells were used as the template. The manufacturer's recommended conditions for long-range amplification and 10-min extension reaction were used after a $60^{\circ} \mathrm{C}$ annealing step. After 35 cycles, amplified fragments were fractionated by agarose gel electrophoresis and stained with ethidium bromide. The amplified fragments were gel-purified, and the nucleotide sequence obtained. The nucleotide sequences obtained were identical to the corresponding regions of the respective EEL reported in GenBank. a 2-kb fragment was identified in a genomic library of $P$. syringae pv. syringae 61 that carries the HrpL-dependent promoter for the $s h c A$-hopPsyA operon. Sequence analysis of this region revealed a homolog of queA and a $\mathrm{tRNA}_{\text {leu }}$ gene, as reported at the time for $P$. syringae pv. syringae $\mathrm{B} 728 \mathrm{~A}$ and $P$. syringae $\mathrm{pv}$. tomato DC3000 (Alfano et al. 2000; A. Collmer, personal communication), and subsequently for $P$. syringae pv. syringae 61 (Alfano et al. 2000). queA is a housekeeping gene involved in the modification of tRNA nucleoside 34 (Reuter et al. 1991) and is not functionally linked to the TTSS, whereas $h r p K$ is thought to be a component of the hrp PAI CCR (Alfano et al. 2000). The presence of these conserved flanking genes adjacent to the EEL introduced the possibility of using polymerase chain reaction (PCR) to amplify the EEL from various $P$. syringae strains for identification of the resident genes. This report describes the properties of the EEL and effectors amplified from 30 strains isolated mostly from North American sources. (A preliminary report of this work has been presented [Hutcheson et al. 2003]).

\section{RESULTS}

Development of a PCR screen for the $P$. syringae EEL.

In order to amplify the EEL from $P$. syringae strains, several primers were constructed, using regions within queA and hrpK that were conserved among alleles found in the previously characterized strains. Different combinations of these primer pairs were then tested for their ability to amplify previously characterized EEL, using commercial long-range PCR amplification kits. A primer pair was identified (K2688 and Q920) that could amplify the EEL from $P$. syringae pv. syringae $61, P$. syringae pv. syringae $\mathrm{B} 728 \mathrm{~A}$ and $P$. syringae pv. tomato DC3000. The expected fragments were detected (Fig. 1) and were identified as EEL by sequence analysis of flanking regions (data not shown). Consistent with the findings of Mansfield and associates (1994), a sequencing error was detected in the originally reported coding sequence for $P$. syringae pv. syringae 61 hrpK (Xiao et al. 1994). The corrected deduced product of $h r p K$ is a 767-aa polypeptide with a predicted mass of $80,070 \mathrm{kDa}$.

\section{Characterization of $h r p K$-associated EEL amplified from $P$. syringae strains.}

Using the primer pair described above, we attempted to amplify the EEL from 86 P. syringae strains, using commercial long range PCR amplification kits, and were successful for 30 predominantly North American $P$. syringae pv. syringae strains isolated from a variety of host plants (Table 1). These amplified EEL were initially classified based on size of the amplified fragment, the nucleotide sequence adjacent to $h r p K$ and queA, and in some cases, the amplification of diagnostic internal fragments. The complete nucleotide sequence was then obtained for at least one representative of each novel type of EEL (Table 1).

Apparent homologs to the EEL of $P$. syringae pv. syringae $61, P$. syringae $\mathrm{pv}$. syringae $\mathrm{B} 728 \mathrm{~A}$, and $P$. syringae pv. tomato DC3000 were detected among the amplified EEL, along with several variants of these EEL. Several previously unreported types of EEL differing from the previously characterized EEL in genetic composition and nucleotide sequence (Fig. 2) were identified among the characterized EEL. These EEL could be further classified into six apparent families that could be distinguished by constituent genes. Strains with the same type of EEL (Table 1) retained $>98 \%$ identity across sequenced portions of the region. Overall, 10 distinct types of EEL were detected among the amplified EEL. Representative strains for each type of EEL are indicated in Table 1.

For several of the strains that were recalcitrant to amplification of the EEL using the $h r p K$ - and queA-derived primers, the 
attempt was made to amplify the EEL using compatible $h r p L$ and queA-derived primers designed using conserved regions of each gene. The EEL of three additional strains were amplified, which, upon characterization as described above, were homologous to one of the EEL amplified in the previous survey. The reason for the inability to amplify the EEL from the other strains has not been determined, but it may be that other types of EEL are carried by these strains, that sequence divergence at the primer sites prevented amplification, or that queA and $h r p K / h r p L$ are not closely linked in these strains.

Family I EEL. Sixteen strains were found to carry an EEL related to that of $P$. syringae pv. syringae 61, henceforth designated Family I EEL (Fig. 2). In eight strains (Table 1), this region was highly conserved (Fig. 2IA). The fragments amplified from these strains were the same size as the fragment amplified from $P$. syringae pv. syringae 61 (Table 1) and the nucleotide sequence of the entire region exhibited $>98 \%$ identity with the $P$. syringae pv. syringae 61 EEL. Strongly conserved homologs of the P. syringae pv. syringae $61 \mathrm{ShcA}$ and HopPsyA were detected ( $>98 \%$ aa identity), and the genetic organization of the locus was conserved relative to the EEL of $P$. syringae pv. syringae 61 .

The EEL of eight additional strains (Table 1) only carried partial homologs to $P$. syringae pv. syringae 61 ShcA and
HopPsyA (Fig. 2IB). The orientation of the two genes was reversed relative to the EEL of $P$. syringae pv. syringae 61, and they appeared to be expressed as part of the hrpK operon. Notably, the apparent translational start of the first open reading frame (ORF), a $s h c A$ homolog designated $s h c B 1$, overlapped the stop codon of $h r p K$, and the stop codon of $s h c B l$ was immediately followed by the translational start of a second ORF, a weak homolog of hopPsyA designated hopPsyB1. Differences were also detected in gene products. For example, the deduced $P$. syringae pv. syringae $\mathrm{B} 5 \mathrm{ShcB} 1$ product was 65 aa longer at the amino terminus than $P$. syringae pv. syringae 61 ShcA and had a predicted mass of $19.5 \mathrm{kDa}$ (Fig. 3A). Three minor sequence variants were detected. Overall, the deduced ShcB1 product shared $56 \%$ identity (I) and 69\% similarity (S) with $P$. syringae pv. syringae 61 ShcA. The $P$. syringae pv. syringae B5 HopPsyB1 encoded a 382-aa polypeptide with a predicted mass of $41.9 \mathrm{kDa}$ (Fig. 3B). The amino terminal $44-$ aa domain retained $68 \%$ I and $82 \% \mathrm{~S}$ with the amino terminus of HopPsyA. This domain, which likely carries the TTSS secretion signal (Mudgett and Staskawicz 1999), was serine rich, as observed in other $P$. syringae TTSS-dependent effectors (Guttman et al. 2002). It did not, however, fit many of the criteria proposed by Petnicki-Ocweija and associates (2002) for TTSS translocated effectors. For example, the deduced

Table 1. Properties of the Pseudomonas syringae strains used in these experiments and the amplified exchangeable effector locus (EEL)

\begin{tabular}{|c|c|c|c|c|c|}
\hline Strain $^{a, b}$ & Plant source $^{c}$ & Geographical location $^{d}$ & Amplified PCR product ${ }^{\mathrm{e}}$ & EEL type $^{\mathrm{f}}$ & Accession no. \\
\hline Psy-B76 & Tomato & GA & 4.0 & IA & \\
\hline Psy-B458 & Orange & $\mathrm{CA}$ & 4.0 & IA & \\
\hline Psy-PDDCC3523 & Tomato & $\mathrm{AU}$ & 4.0 & IA & \\
\hline Psy-PS-1 & Peach & $\mathrm{NC}$ & 4.0 & IA & \\
\hline Psy-PS-14 & Apricot & $\mathrm{NC}$ & 4.0 & IA & \\
\hline Psy-Ps6-SB & Soybean & $\mathrm{NE}$ & 4.0 & IA & \\
\hline Psy-84-15 & Tomato & GA & 4.0 & IA & \\
\hline Psy-85-274 & Tomato & GA & 4.0 & IA & \\
\hline Psy-B5 & Soybean & MC & 3.5 & IB & AY147022 \\
\hline Psy-B6 & Soybean & $\mathrm{MC}$ & 3.5 & IB & AY147023 \\
\hline Psy-464 & Corn & $\mathrm{SD}$ & 3.5 & IB & AY147017 \\
\hline Psy-B301D & Pear & UK & 3.5 & IB & AY147020 \\
\hline Psy-BK034 & Wheat & $\mathrm{MN}$ & 3.5 & IB & AY147024 \\
\hline Psy-PDDCC3907 & Pear & GR & 3.5 & IB & AY147027 \\
\hline Psm-567 & Cherry & UK & 3.5 & IB & \\
\hline Psy-5D4198 & Plum & CA & 8.0 & IC & AY147019 \\
\hline Pph-BK378 & Bean & MN & 4.0 & II & AY147025 \\
\hline Pph-B130 & Bean & GA & 4.0 & II & \\
\hline Psy-B362 & Bean & $\mathrm{CA}$ & 8.5 & IIIA & \\
\hline Psy-Ps1Bean & Bean & WA & 8.5 & IIIA & \\
\hline Psy-B452 & Orange & CA & 5.5 & IIIB & AY147021 \\
\hline Psy-B460 & Lemon & $\mathrm{CA}$ & 5.5 & IIIB & \\
\hline Psy-BK035 & Wild Rice & $\mathrm{MN}$ & 5.5 & IIIB & \\
\hline Psy-W4N15 & Apple & WA & 5.5 & IV & AY147028 \\
\hline Psy-W4N27 & Pear & OR & 5.5 & IV & \\
\hline Psy-NCPPB1053 & Millet & ET & 7.5 & VA & \\
\hline Pto-2844 & Tomato & UK & 7.5 & VA & \\
\hline Ppe-5846 & Peach & FR & 6.0 & VB & AY147018 \\
\hline Psy-DH015 & Bean & WI & 5.0 & VI & AY147026 \\
\hline
\end{tabular}

${ }^{a}$ See Denny et al. 1988 for references for the listed strains. Abbreviations: Pmo, P. syringae pv. morsprunorum; Ppe, P. syringae pv. persicae; Pph, P. syringae pv. phaseolicola; Psy, $P$. syringae pv. syringae; Pto, $P$. syringae pv. tomato. Representative strains used for each type of EEL are shown in bold. Psy-61, Psy-B728A and Pto-DC3000 were used as the representative strains for type IA, IIIA, and VA EEL.

b The following strains were negative for PCR amplification of the EEL using Q920 and K2468: Psy-480, P. syringae pv. delphinii-529, Pto-2424, P. syringae pv. berberidis-4116, P. syringae pv. antirrhini-4303, P. syringae pv. savastanoi-4352, Pmo-5795, P. syringae pv. maculicola (Pma)-\#1, Pma-\#5, Pma-\#10, Pma-1083-3, Psy-5D417, Pto-832F, Pto-B117, Pto-B118, Pto-B120, Pto-B121, Pto-B122, Pto-B125, Psy-B15, Pto-B19, Psy-B359, Psy-B368, Psy-B382, Psy-B3A, Psy-B407, Psy-B427, Psy-B455, Pto-B67, Pto-B88, Psy-BK036, Pto-CNBP1323, Pto-DAR26742, Pto-30555, Pto-DAR31861, Psy-HS191, Pto-JL1053, Pto-JL1060, Pto-JL1075, Pto-JL1105, Pto-JL1120, Pto-NCPPB880, Pph-NK343, Pto-PDDCC 3357, Pto-PDDCC 4355, PtoPT14, Pto-PT21, Pto-PT30, Pto-RG-4, Psy-S-4B-1, Psy-SD19, Pto-T1, Pto-T4B1, Psy-W4N108, Psy-W4N43.

${ }^{c}$ Host plant from which the strain was isolated from or reported to cause symptoms.

${ }^{\mathrm{d}}$ Geographical region where the strain was isolated. Abbreviations: AU, Australia; CA, California, U.S.A.; ET, Ethiopia; FR, France; GA, Georgia, U.S.A.; GR, Greece; MC, Manitoba, Canada; MN, Minnesota, U.S.A.; NC, North Carolina, U.S.A.; NE, Nebraska, U.S.A.; OR, Oregon, U.S.A.; SD, South Dakota, U.S.A.; UK, United Kingdom; WA, Washington, U.S.A.; WI, Wisconsin, U.S.A.

e The indicated strain was used to initiate PCR amplification of the EEL using primers Q920 and K2468 as described in the Materials and Methods. The size indicated was determined by agarose gel electrophoresis and represents the amplified EEL plus $1.5 \mathrm{~kb}$ of sequence internal to queA and $h r p K$.

${ }^{\mathrm{f}}$ Genetic organization of EEL families is shown in Figure 2. Placement into the indicated families was based upon sequence similarities. 
HopPsyB 1 product had hydrophobic amino acids at positions 3 and 4 , carried a glutamic acid at position 12 , and had multiple cysteines in the polypeptide. However, other translocated effectors, such as HopPsyA, also displayed these characteristics (data not shown). Overall, the HopPsyB1 polypeptide exhibited $31 \%$ I and $45 \% \mathrm{~S}$ with HopPsyA and required several gaps to align with HopPsyA. This suggests that the effector activity of the two proteins may be different. Since the EEL of these strains appeared to be an inversion of a $P$. syringae pv. syringae 61-like EEL, they were retained as a Family I EEL.

A third variant of the Family I EEL was identified in strain $P$. syringae pv. syringae 5D4198. This strain retained the $P$. syringae pv. syringae $\mathrm{B} 5$-like $\mathrm{ShcB}$ and HopPsyB alleles ( $>97 \%$ aa identity) but carried three additional genes, eelA, $e e l B$, and eelC, immediately downstream of the hopPsyB2 allele, that have unknown functions (Fig. 2IC). EelA encoded a 256-aa polypeptide with a predicted mass of $30 \mathrm{kDa}$. EelB is predicted to be a 243-aa product with a mass of $27.2 \mathrm{kDa}$, whereas EelC is a 545-aa polypeptide with a predicted mass of $62 \mathrm{kDa}$. Neither homologs nor conserved functional domains were detected in the databases for any of the three proteins. No obvious secretion signals were apparent. A partial duplication of the $\mathrm{tRNA}_{\text {leu }}$ gene was detected, suggesting that eelA and $e e l B C$ are part of a 4-kb insertion into the tRNA gene. Consistent with this interpretation, the nucleotide sequence of the region between the truncated $\mathrm{RNA}_{\text {leu }}$ gene and $P$. syringae pv. syringae 5D4198 hopPsyB2 retained 95\% identity with the corresponding region of the $P$. syringae pv. syringae B5 EEL. No obvious HrpL-dependent promoters were detected in the apparent promoter region between the divergently expressed $P$. syringae pv. syringae 5D4198 eelA and eelBC, suggesting that neither are part of the HrpL-dependent regulon. eelBC likely form an operon, since they are expressed collinearly, and no obvious transcriptional terminators were detected in the intergenic region between them.

Family II EEL. The EEL of $P$. syringae pv. phaseolicola BK378 and $P$. syringae pv. phaseolicola B130 consisted of two genes, one of which was a strong homolog to the AvrPphE allele originally described for $P$. syringae pv. phaseolicola 1032A (race 4) (Mansfield et al. 1994)(Fig. 2). This EEL amplified as a 4-kb fragment (Table 1), and the nucleotide sequence of the $P$. syringae pv. phaseolicola BK378 avrPphE homolog retained $>98 \%$ identity with the reported sequence for avrPphE of $P$. syringae pv. phaseolicola 1032A. Residues G191, W235, and E310, which have been reported to be essential for R2-specific 'avirulence' activity (Stevens et al. 1998), were conserved in this allele, but the $P$. syringae pv. phaseolicola BK378 AvrPphE homolog was 60 aa longer than its 1032A homolog. This carboxy terminal extension was nearly identical to the carboxy terminal extension present in avrPphE8 allele (Stevens et al. 1998), and this designation was retained. The 95-bp P. syringae pv. phaseolicola BK378 hrpKavrPphE8 intergenic region exhibited little sequence similarity with the corresponding regions of Family III and IV EEL, which also carried alleles of AvrPphE (less than $41 \%$ identity with either the hopPsyCl-avrPphE or hrpK- hopPsyCl intergenic regions [data not shown]). This indicates that the genetic arrangement of Family II EEL was unlikely to be the result of a deletion event that occurred in a Family III or Family IV EEL and, conversely, that Family III and Family IV EEL did not arise due to an insertion event.

A second ORF, designated eelF4, was identified 154 bp downstream of the $P$. syringae pv. phaseolicola BK378 and $P$. syringae pv. phaseolicola B130 avrPphE homologs that exhibited $83 \%$ I and $87 \% \mathrm{~S}$ with ORF 3 (eelF1) of the Family IV EEL of $P$. syringae pv. tomato DC3000 described below. EelF4 lacked homologs of known function and was unusual because, whereas EelF1 consisted of six 17-aa repeats and exhibited properties suggestive of an outer membrane localization, the EelF4 was missing the fifth repeat. Possible functions of this gene product have not yet been explored.

Homologs to queA and the gene for $\mathrm{RNA}_{\text {leu }}$ were also detected flanking Family II EEL (Fig. 2). Although nearly identical avrPphE alleles had been identified in the EEL of $P$. syringae pv. phaseolicola 1032A (Mansfield et al. 1994; Stevens et al. 1998), the chromosomal location of the hrp PAI in this strain had not been established. The ability to amplify a closely related EEL from several strains carrying Family II EEL using $q u e A$ - and $h r p K$-specific primers and the detection of queA and tRNA $_{\text {leu }}$ homologs adjacent to this EEL indicated that the chromosomal location of the hrp PAI in strains carrying Family II EEL is identical to those strains with characterized EEL.

Family III EEL. Two strains were identified that carried a $P$. syringae pv. syringae B728A-like Family III EEL. The fragments amplified in the initial PCR were of similar size to the EEL amplified from $P$. syringae pv. syringae B728A (Fig. 1; Table 1), and the 600-nt sequence at each end of the amplified fragments exhibited strong sequence similarity ( $>98 \%$ identity) to the EEL of $P$. syringae pv. syringae B728A (data not shown). To determine if the strains carrying the $P$. syringae pv. syringae B728A-like EEL retained all six ORFs identified in the $P$. syringae pv. syringae B728A EEL, a PCR screen was used to amplify diagnostic fragments extending between adjacent genes, using gene-specific primers as described below. The expected fragments could be amplified from the EEL for each of these strains (data not shown), indicating that the genetic organization was conserved, but no attempt was made to further identify strain-specific sequence polymorphisms that could be present in these EEL. Proposed genetic designations for each of the detected genes are shown in Figure 2.

Three additional strains were identified that carried truncated versions of the Family III EEL (Fig. 2IIIB). Although the EEL of these strains retained a partial homolog of $P$. syringae pv. syringae $\mathrm{B} 728 \mathrm{~A}$ HopPsyC1 and the queA-associated sequences exhibited at least $95 \%$ identity at the nucleotide level to the corresponding region of $P$. syringae pv. syringae B728A, the amplified EEL was $3 \mathrm{~kb}$ smaller than the $P$. syringae pv. syringae B728A EEL (Table 1). A PCR screen similar to the one used to screen full size $P$. syringae pv. syringae B728A-like EEL indicated that these strains lack the $\operatorname{avrPphE}$ allele as well as the transposition-associated eelDE operon. Sequence analysis of the $P$. syringae pv. syringae B452 EEL confirmed the deletion in these genes and revealed a nearly complete deletion of the hopPsyC allele. Only the N-terminal 3 to 71 aa were conserved, and the truncated ORF lacked both the probable ribosome binding site and the start codon. The remaining hrpK'hopPsyC' intergenic region, however, was nearly identical to the corresponding region of the $P$. syringae pv. syringae B728A EEL. Homologs of $s h c V$ encoding an apparent chaperone (van Dijk et al. 2002) and the avrXct-like hopPsyV were present. In P. syringae pv. syringae B452, the hopPsyV2 allele included a frameshift mutation in codon 208 that likely inactivates effector activity. The intergenic sequences were conserved, indicating that the EEL of these strains were likely deletion derivatives of a $P$. syringae pv. syringae B728A-like EEL and, hence, their classification as part of this EEL family.

Family IV EEL. A fourth family of EEL was identified in $P$. syringae pv. syringae W4N15 (type strain) and $P$. syringae pv. syringae W4N27 (Table 1), which consisted of four genes (Fig. 2 ). The EEL of these strains contained the hrpK-hopPsyClhopPsyE1 operon found in the Family III EEL and homologs to eelF1 and eelG2 of the Family V EEL found in P. syringae pv. tomato DC3000. The W4N15 HopPsyC2 retained 74\% I and $80 \% \mathrm{~S}$ to the $P$. syringae pv. syringae B728A HopPsyC1 (ORF 
1) product, both of which also exhibited weak similarity to AvrPphC. The $P$. syringae pv. syringae W4N15 HopPsyE2 homolog was $97 \%$ identical to the $P$. syringae pv. syringae B728A HopPsyE1. P. syringae pv. syringae W4N15 EelF3 and EelG3 exhibited $85 \%$ and $89 \%$ identity with $P$. syringae pv. tomato DC3000 EelF1 and EelG1.

Family V EEL. Three strains were identified whose EEL was nearly identical to the EEL described for $P$. syringae pv. tomato DC3000 (Table 1). The amplified regions from each strain were the same size as the EEL amplified from $P$. syringae pv. tomato DC3000 (type strain) and the initial sequences were nearly identical to that of the $P$. syringae pv. tomato DC3000 EEL. Similar to the experiments described for Family III EEL, diagnostic fragments linking adjacent genes could be amplified that were of similar size to those amplified from $P$. syringae pv. tomato DC3000 (data not shown), indicating that the genetic organization of these Family V EEL was likely conserved in these strains (Fig. 2). As before, no attempt was made to further identify sequence polymorphisms in these strains.

A variant of the $P$. syringae pv. tomato DC3000 EEL was identified in $P$. syringae pv. persicae 5846. The EEL of $P$. syringae pv. persicae 5846 was $2.5 \mathrm{~kb}$ smaller than the $P$. syringae pv. tomato DC3000 EEL (Table 1), but sequence analysis of the region flanking $h r p K$ showed high sequence identity to P. syringae pv. tomato DC3000 hopPtoB. The 5846 HopPtoB homolog, HopPtoB5, retained $99 \%$ aa sequence identity to its $P$. syringae pv. tomato DC3000 homolog over the majority of its length but contained a 138-aa C terminal deletion. Since the activity of HopPtoB has not been established, it is unclear whether $P$. syringae pv. persicae 5846 HopPtoB5 retains similar function to the $P$. syringae pv. tomato DC3000 HopPtoB. Nonetheless, the $P$. syringae pv. persicae 5846 HopPtoB5 is likely secreted by the $h r p$ TTSS, since the amino termini of the two proteins are identical. Sequence analysis revealed that the deletion detected within the $P$. syringae pv. persicae 5846 EEL extended into the eelG allele. The $P$. syringae pv. persicae 5846 eelG2 lacked the coding sequence for the C-terminal 53 aa of other eelG alleles. The remaining polypeptide retained $99 \%$ aa identity to $P$. syringae pv. tomato DC3000 EelG1. In the $P$. syringae pv. persicae $5846 \mathrm{EEL}$, IS53-like sequences were also detected between the 5846 hopPtoB5 and eelG2 (Fig. 2).

Family VI EEL. A distinct EEL was identified in P. syringae pv. syringae DH015 (Table 1). Although superficially similar to the EEL of $P$. syringae pv. tomato DC3000, the EEL of this strain was $2.5 \mathrm{~kb}$ smaller. Only partial sequence similarity was
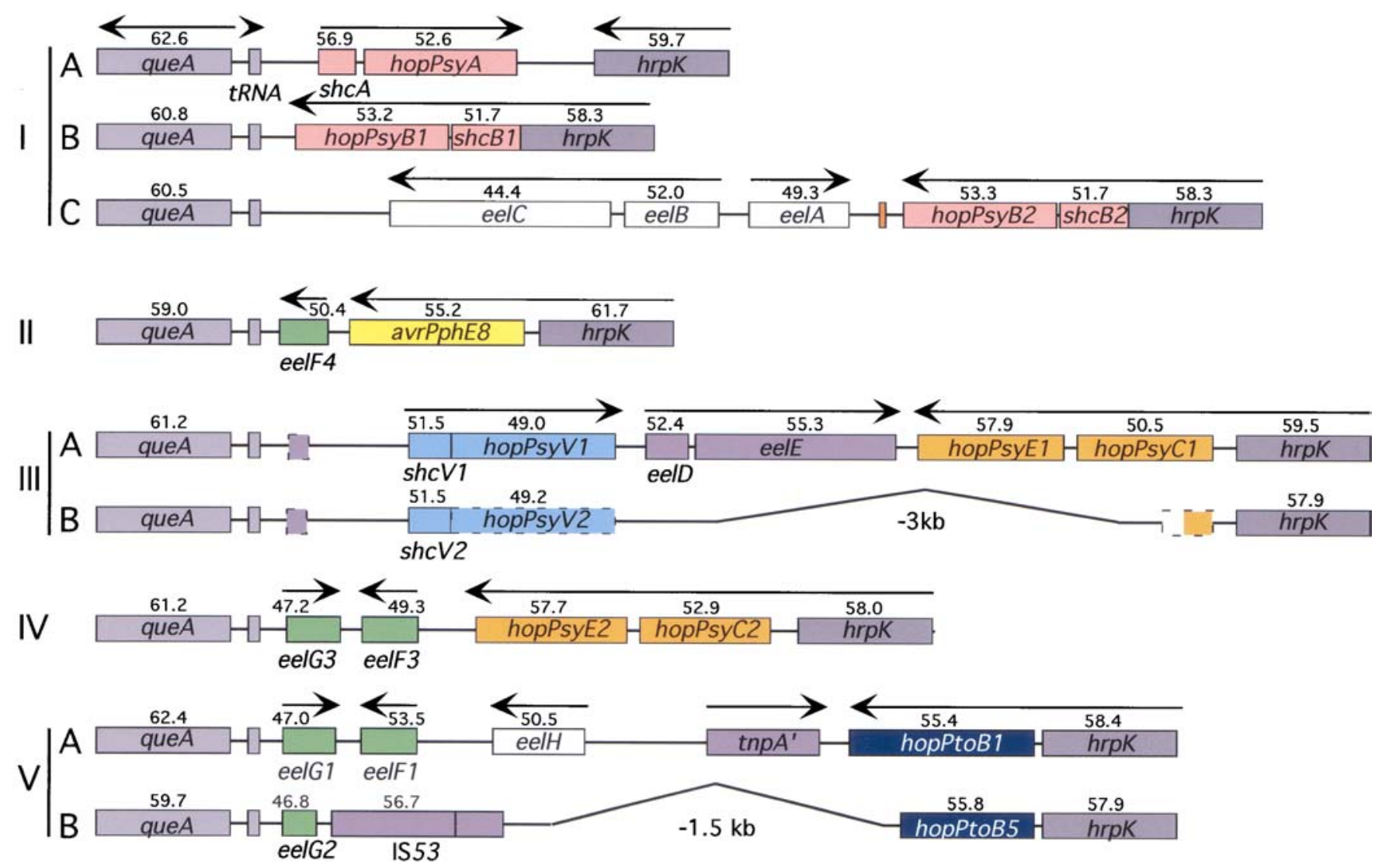

$\mathrm{VI}$
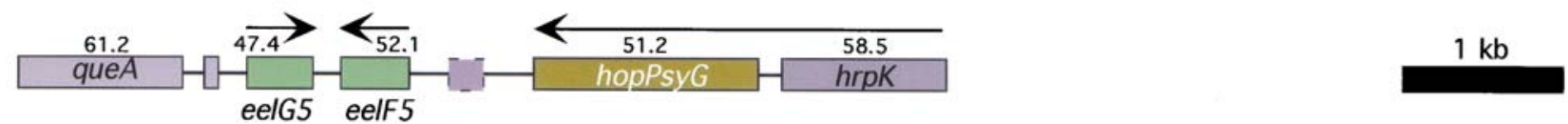

Fig. 2. The exchangeable effector loci (EEL) amplified from Pseudomonas syringae strains. The EEL was amplified, and the complete nucleotide sequence was obtained. The EEL for strains shown in bold in Table 1 were used as representatives of each type of EEL. The $P$. syringae pv. syringae 61 EEL served as the representative for the type IA EEL, and the $P$. syringae pv. syringae B728A and $P$. syringae pv. tomato DC3000 EEL were used for type IIIA and type VA EEL, respectively. Known or deduced genes are indicated by the filled and labeled boxes. Boxes with dashed line borders indicate probable pseudogenes that lacked translational initiation signals or appeared to be gene fragments. Apparent transcription units are shown by the arrows. If no arrow is shown the organization is conserved relative to the EEL shown above. Strains sharing similar or related genetic compositions are grouped into families labeled with Roman numerals, and variants of each family are indicated by upper case letters on the left. Strains carrying the indicated variants of the EEL are shown in Table 1. Boxes filled with the same color indicate apparent gene cassettes. Apparent transposable elements are shown in purple. Deletions are indicated by the labeled bridges. The numbers above the boxes represent the percent GC for the adjacent coding sequence. 
detected between the first ORF the $P$. syringae pv. syringae DH015 EEL, designated as hopPsyG, and the $P$. syringae pv. tomato DC3000 hopPtoB locus. In addition, the hrpK-hopPsyG intergenic region was larger and lacked sequence similarity to its $P$. syringae pv. tomato DC3000 counterpart. A similar result was obtained for the hopPsyG-eelF5 intergenic region, indicating that this EEL was unlikely to be a deletion derivative of a Family V EEL. The $P$. syringae pv. syringae DH015 HopPsyG product was of similar size to the $P$. syringae pv. tomato DC3000 HopPtoB product but retained only 50\% identity at the amino acid level. Most predicted properties of known TTSS-secreted effectors (Petnicki-Ocweija et al. 2002) were retained in HopPsyG. EelF5 and EelG5 showed stronger similarity to their counterparts of the $P$. syringae pv. tomato DC3000 EEL. The $P$. syringae pv. syringae DH015 EelF5 shared $78 \%$ identity with EelF1 of $P$. syringae pv. tomato DC3000, whereas the $P$. syringae pv. syringae DH015 EelG5 retained $88 \%$ identity with the $P$. syringae pv. tomato DC3000 EelG1. The apparent Family VI EEL can be distinguished from Family V EEL by the divergent HopPsyG allele and its flanking intergenic regions.

\section{Identification of gene cassettes conserved among several EEL.}

Several sets of genes appeared to be conserved between EEL families. For example, alleles of hopPsyC-hopPsyE present in Family III EEL were also present in Family IV EEL. To determine if these genes were part of conserved gene cassettes, the nucleotide sequences of noncoding intergenic and flanking regions were compared. Within the apparent W4N15 (Family IV) hopPsyC2-hopPsyE2 cassette, intergenic regions were highly conserved with corresponding regions of Family III EEL (Fig. 4, regions D, E, and F). For example, the 190-bp hrpKhopPsyC2 intergenic region (Fig. 4, region D) retained $98 \%$ identity, and the 148-bp hopPsyC2-hopPsyE2 intergenic region (Fig. 4, region E) exhibited $92 \%$ identity with corresponding regions of the $P$. syringae pv. syringae $\mathrm{B} 728 \mathrm{~A}$ hopPsyC1hopPsyE1 cassette. This conservation extended 85 bp past the $3^{\prime}$ end of the hopPsyE coding sequence (Fig. 4, region F). Thus, flanking, coding, and intergenic regions of this cassette are conserved in both types of EEL.

Similarly, convergently expressed eelF1 and eelG1 of Family V EEL were detected in Family II, IV, and VI EEL as part of an apparent gene cassette. Like above, the 154-bp intergenic region between the $P$. syringae pv. tomato DC3000 eelF1 and eelG1 (Fig. 4, region $\mathrm{H}$ ) retained $91 \%$ identity with the corresponding regions of $P$. syringae pv. syringae W4N15 or $P$. syringae pv. syringae DH015. High identity (93\%) was also observed in the $300-\mathrm{bp}$ region $5^{\prime}$ to eelF in strains $P$. syringae pv. syringae $\mathrm{DH} 015$ and $P$. syringae pv. syringae W4N15 (labeled $\mathrm{G}$ in Figure 4), but only $50 \%$ identity was detected to this region of $P$. syringae pv. tomato DC3000, while in other strains higher conservation was observed. The 100 -bp region $5^{\prime}$ to eelG (Fig. 4, region I) also exhibited $>75 \%$ sequence identity in $P$. syringae pv. tomato DC3000, $P$. syringae pv. persicae $5846, P$. syringae pv. syringae $\mathrm{W} 4 \mathrm{~N} 15$, and $P$. syringae pv. syringae $\mathrm{DH} 015$. Two modified forms of the eelF-eelG cassette were also detected. In the type VB EEL of strain $P$. syringae pv. persicae 5846, the region $5^{\prime}$ to eelG2 (Fig. 4, region I) retained at least $80 \%$ identity with corresponding regions of the P. syringae pv. tomato $\mathrm{DC} 3000, P$. syringae pv. syringae W4N15, and $P$. syringae pv. syringae DH015 EEL, but other portions of the cassette were deleted as described above.

The eelF4 of Family II EEL also appears to have been derived from the eelF-eelG gene cassette. The 154-bp region $5^{\prime}$ to eelF4 (Fig. 4, region $\mathrm{G}$ ) retained $85 \%$ identity with the corresponding region of the $P$. syringae pv. syringae $\mathrm{DH} 015$ and $P$. syringae pv. syringae W4N15 EEL. In contrast, the 129-bp region next to the tRNA gene appeared to be a chimera between the tRNA-eelG intergenic region (Fig. 4, region I) and the eelG-eelF intergenic region (Fig. 4, region $\mathrm{H}$ ). Approximately $36 \mathrm{bp}$ adjacent to the $3^{\prime}$ end of eelF4 were nearly identical to the eelF-eelG intergenic region of $P$. syringae pv. tomato DC3000, W4N15, and DH015. The remaining $31 \mathrm{nt}$ after subtraction of the generally conserved 62-bp region next to the tRNA gene exhibited strong sequence similarity to the corresponding portion of the tRNA-eelG region of $P$. syringae pv. tomato DC3000, P. syringae pv. syringae $\mathrm{W} 4 \mathrm{~N} 15$, and $P$. syringae pv. syringae DH015.

Consistent with the presence of apparent gene cassettes, the percent GC content of the EEL exhibited mosaicism. While the percent GC of other portions of the hrp PAI were around $58.7 \%$, many of the genes identified in the characterized EEL were closer to $50 \% \mathrm{GC}$ (Fig. 2). In contrast, the sequenced portions of $h r p K$ were $58.8 \pm 1.2 \% \mathrm{GC}$, and those of queA were $60.9 \pm 1.1 \%$ GC. Thus, the percent GC of EEL genes is significantly different from other chromosomal or PAI genes. This suggests these apparent cassettes were acquired by horizontal transfer.

\section{Analysis of queA and $\mathbf{h r p K}$ sequence variants.}

The amplified EEL from the aforementioned strains also carried portions of queA and $h r p K$. To determine if there was evolutionary relationship of either gene with the adjacent gene cassettes, the partial queA and $h r p K$ sequences were subjected to phylogenetic analyses. Insufficient sequence polymorphisms were detected in the approximately 100-bp portion of queA that was sequenced to use in phylogenetic analyses. The hrpK locus, however, was highly polymorphic, and numerous base substitutions were detected that were parsimony informative. Although the sampled sequence was relatively small (231 bp), 69 bases were variable. Using this information, two distinct clusters of $h r p K$ variants were identified after minimum evolution and maximum likelihood analysis using PAUP*4.0. The $h r p K$ of strains carrying a Family V EEL formed a separate cluster with strong bootstrap support (100\%) from the hrpK of strains with other types of EEL (Fig. 5). Although some correlations were detected between resident EEL of other families and the adjacent hrpK allele, there was insufficient bootstrap support of the phylogenetic tree to defend the apparent correlations.

\section{Linkage}

between EEL, host range, and geographical source.

Few correlations were detected between the resident EEL and the apparent host range of strains, as expected. Strains carrying type IIIA EEL tended to be bean pathogens isolated in North America, but bean pathogens were found among the strains carrying other types of EEL (Table 1). Strains carrying Family IV EEL were apparent pathogens of Roseaceae plants; nonetheless, strains with apparently similar host ranges were found to carry other types of EEL. Some groups of EEL showed no correlation with host range. For example, included among the nine strains carrying a type IA EEL were tomato, soybean, citrus, and Prunus sp. pathogens (Table 1). Tomato and Prunus pathogens were also identified among the strains carrying type VA EEL, and citrus pathogens were also found among the strains carrying a type IIIB EEL. The inability to link the apparent host range of a strain with the resident EEL is consistent with current models that predict that multiple effectors control host range of a strain (Fouts et al. 2002; Hutcheson 1998). A possible geographical correlation was noted, however. Strains carrying Family V EEL were either isolated or derived from strains isolated in the U.K., France, or North Africa. Strains carrying other types of 
EEL were predominately North American isolates. As most strains surveyed in this study were of an apparent North American origin, additional studies are required to confirm this possible geographical relationship.
The Family I Orf 2 encodes a translocated effector.

In EEL Families II to V, sequence variants of known effectors were identified that retained at least $75 \%$ sequence identity and carried strong conserved amino termini, suggesting that
A

B5

46

5D4198

ShCA

B5

464

$5 \mathrm{D} 4198$

ShCA

B5

464

5D4198

ShCA
1 MQWSRAATLSSVIFRECVVLQTSMINTPPGEVIYRPRSFVQCSGHRGVLMTDRLYKTVLA
1 MQWSRAA-LSSILFRECVVLQTSMINTPPGEVIYRPRPFVQCSGHPGVLMTDRLYKTVLA
1 MQWSRAAALSSILFRECVVLQTSMINTPPGEVIYRPRPFVQCSGHRGVLMTDRLYKTVLA

\title{
B
}

B5

464

5D4198

HopPsyA

120 GALNPLFNDGPGLGWHAGSELYIGFKAIPRENVSVVTLKQAIAELVEWIKRWRDAH-

119 GALNPLFNDGPGLGWHAGSELYIGFKAIPRENVSVVTLKQAIAELVEWIKTWRDAH -

120 GALNPLFNDGPGLGWHAGSELYIGFKAI PRENVSVVTLKQAIAELVEWIKTWRDAH-

56 GALNPLVNAGPGIGWDEQSGLYHAYQSI PREKVSVEMLKLEIAGLVEWMKCWREART

\begin{abstract}
B5 61 FFKKAGLSGSSGSQSDQIAQVLNDKRGSSVSRLIRQGQTHLGRMQFNIEEGQGSSAATSV
46461 FFKKAGLSGSSGSQSDQIAQVLNDKRGSSVPRLMRQGQTHLGRMQFNIEEGQGSSAATSV

5D4198 61 FFKKAGLSGSSGSQSDQIAQVLNDKRGSSVPRLIRQGQTHLGRMQFNIEEGQGSSAATSV

HopPsyA 61 FFKGAAHLIGGQSQRAQIAQVLN-EKAAAVPRLDR----MLGRRFDLEKGGSSAVGAAIK
\end{abstract}

B5 121 QNSRLPNGRLVNSSILQWAEKAKANGSTSSSALYQIYAKELPRVELLPRTEHRACLAHMY

464121 QNSRLPNGRLVNSSILQWAEKAKANGSTSSSALYQIYAKELPRVELLPRTEHRACLAHMY

5D4198 121 QNSRLPNGRLVNSSILQWAEKAKANGSTSTSALYQIYAKELPRVELLPRTEHRACLAHMY

HopPSYA 116 AADSRLTSKQTFASFQQWAEKAEALGRYRNRYLHDLQEGHARHNAYECGRVIKNITWKRYR

$\begin{array}{llll}\text { B5 } & 181 & \text { KLNGKDGISIWPQFLDGVRGLQLKHDTKVFMMNNPKAADEFYKIERSGTQFPDEAVKARL } \\ 464 & 181 & \text { KLNGKDGISIWPQFLDGVRGLQLKHDTKVFMMNNPKAADEFYKIERSGTQFPDEAVKARL } \\ \text { 5D4198 } & 181 & \text { KLNGKDGISIWPQFLDGVRGLQLKHDTKVFMMNNPKAADEFYKIERSGTQFPDEAVKARL } \\ \text { HopPSYA } & 176 & \text { LSITRKTLSYAPQIHDDRE--EEELDLGRYIAEDRNARTGFFRMVPK-DQRAPETNSGRL }\end{array}$

B5 241 TINVKPQFQKAMVDAAVRLTAERHDIITAKVAGPAKIGTITDAAVFYVSGDFSAAQTLAK

464241 TINVKPQFQKAMVDAAVRLTAERHDI ITAKVAGPAKIGTITDAAVFYVSGDFSAAQTLAK

5D4198 241 TINVKPQFQKAMVDAAVRLTAERHDIITAKVAGPAKIGTITDAAVFYVSGDFSAAQTLVK

HopPSYA 233 TIGVEPKYGAQLALAMATLMDKHKSVTQGKVVGPAKYGQQTDSAILYINGDLAKAVKLGE

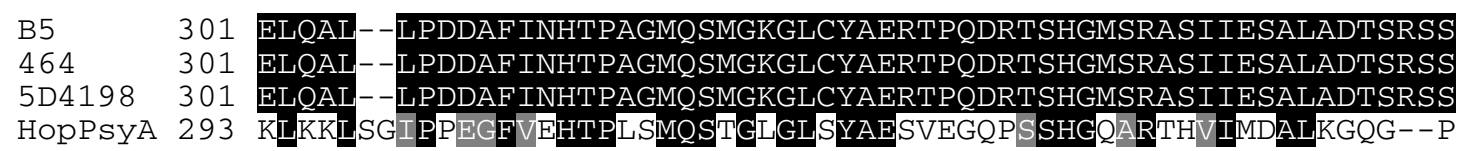

$\begin{array}{lll}\text { B5 } & 359 & \text { LEKKLRNAFKSAGYNPDNPAFRLE- } \\ 464 & 359 & \text { LEKKLRNAFKSAGYNPDNPAFRLE- } \\ \text { 5D4198 } & 359 & \text { LEKKLRNAFKSAGYNPDNPAFRLE- } \\ \text { HopPSYA } & 351 & \text { MENRLKMALAERGYDPENPALRARN }\end{array}$

Fig. 3. Sequence alignments between A, ShcA orthologs and B, HopPsyA orthologs. The deduced amino acid sequences for representative ShcB and HopPsyB products are shown. The sequences were aligned to the $P$. syringae pv. syringae 61 ShcA or $P$. syringae pv. syringae 61 HopPsyA using the ClustalW algorithm and displayed using the Boxshade output. Identical amino acids are highlighted with black, whereas similar amino acid residues are shown in gray. 
they are alleles of known effectors. Thus, the EEL of these families, with the possible exception of the P. syringae pv. persicae 5846 type VB EEL, appear to express at least one functional effector. Family IB and IC HopPsyB, in contrast, only retained $31 \%$ identity with the known effector, HopPsyA. The apparent retention of an amino terminal TTSS secretion signal and association with a ShcA-like apparent chaperone suggested that this locus might also encode a translocated effector. The $P$. syringae pv. syringae B5 EEL was cloned into pDSK600, such that $s h c B 1-h o p P s y B 1$ operon was expressed from the vector's $\mathrm{P}_{\text {lacUv5 }}$ promoters to create pSHB5EEL1-600. When this construct was transformed into Escherichia coli MC4100 (pHIR11-2070)(pYXL2B), a strain that had been used previously to test for hrp TTSS-dependent effector activity (Pirhonen et al. 1996), transformants exhibited an $\mathrm{HR}^{+}$phenotype in tobacco leaves, consistent with the presence of effector activity (Table 2).

To confirm that the HopPsyB product is translocated into host cells by the hrp TTSS, a fusion was constructed between the amino terminal 78 aa of HopPsyB1 and 'AvrRpt2 in pJCB5EEL2-AR2, and the resulting fusion was screened for activity in RPS2 and rps 2 lines of A. thaliana (Guttman et al. 2002). P. syringae pv. tomato DC3000 (pJCB5EEL2-AR2) elicited the HR in A. thaliana ecotype Columbia (RPS2) but not in the rps 2 derivative (Table 2). These observations are consistent with translocation of HopPsyB into host cells and indicate that HopPsyB, like HopPsyA, is a TTSS-dependent effector.

When tested for an effect on the virulence of $P$. syringae pv. tomato DC3000 in A. thaliana (Whalen et al. 1991) and several Brassica oleracea cultivars (C. Bender, personal communication), $P$. syringae pv. tomato DC3000 transformants carrying pSHB5EEL1-600 exhibited a slight reduction in virulence on $A$. thaliana but showed slightly enhanced virulence in some $B$. oleracea lines (Table 2). Populations of $P$. syringae pv. tomato DC3000 (pSHB5EEL1-600) were consistently higher than $P$.

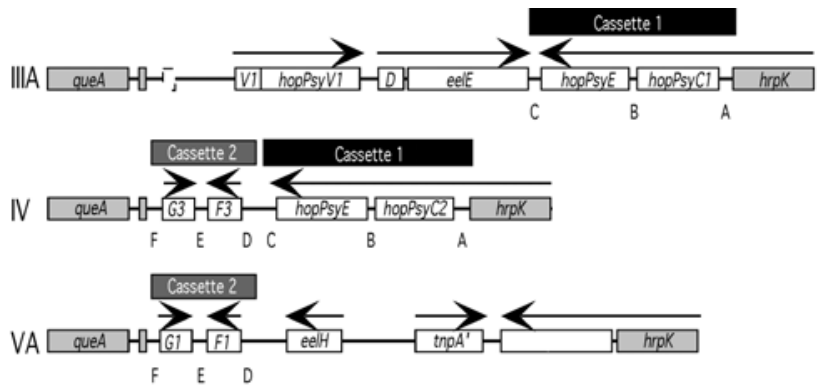

\begin{tabular}{clcc}
\hline Region & Location & Size(bp) & \% Identity \\
\hline A & hrpK-hopPsyC & 190 & 98 \\
B & hopPsyC-hopPsyE & 148 & 92 \\
C & hopPsyE-eelE & 85 & 98 \\
D & eelF-hopPsyE & 150 & 50 \\
E & eelF-eelG & 154 & 91 \\
F & eelG-tRNA & 170 & 86
\end{tabular}

Fig. 4. Conserved gene cassettes identified in the Pseudomonas syringae hrp pathogenicity island exchangeable effector loci. Proposed gene cassettes are indicated by the bars. The conservation of intergenic region indicated by the upper case letter (Region) is shown. The size of the indicated intergenic region is reported in base pairs (bp), and the calculated percent identity for this region (I) is reported after alignment using ClustalW. The indicated sequences from $P$. syringae pv. syringae B728A and $P$. syringae pv. syringae W4N15 were used to compare regions $\mathrm{A}, \mathrm{B}$, and $\mathrm{C}$. The sequences from $P$. syringae pv. syringae W4N15 and $P$. syringae pv. tomato DC3000 were used for regions D, E, and F. Similar results were obtained during comparison of regions D, E, and F from $P$. syringae pv. tomato DC3000 with those from DH015, except that region D retained $94 \%$ identity. syringae pv. tomato DC3000 alone or the transformant expressing the $P$. syringae pv. syringae 61 EEL. In contrast, growth of $P$. syringae pv. tomato DC3000 (pYX1L) expressing HopPsyA was reduced in these same cultivars. Symptom formation roughly paralleled the population levels. The responses in the B. oleracea varieties did not seem to be classical $R$ genemediated responses. E coli expressing the hrp TTSS and HopPsyA and HopPsyB did not elicit the HR in these plants (Table 2) as observed with other $a v r$ genes (Pirhonen et al. 1996).

\section{DISCUSSION}

The EEL of the hrp PAI is one source for effectors, and unique EEL expressing distinct effectors had been identified in each of the previously characterized PAI of $P$. syringae strains (Alfano et al. 2000; Hutcheson 1999). To identify novel effectors that could function in $P$. syringae pathogenicity, the attempt was made to amplify and characterize the EEL from 86 $P$. syringae strains. The EEL was successfully amplified from 33 of these $P$. syringae strains that had been isolated primarily in North America from a diversity of hosts. The results presented here indicate that each strain does not carry a unique EEL. Additional strains of distinct host range were identified that carried an EEL related to one of the four previously characterized EEL. Several variants of previously characterized EEL as well as apparently novel types of EEL were identified among the amplified EEL. Some of these EEL retained sufficient similarity to be grouped into six apparent families that differed in genetic composition. As expected, no apparent correlation was detected between resident EEL and host range of a strain.

Candidate effectors were found in each of the newly characterized EEL that differed in sequence or length from previously characterized homologs. For example, HopPsyB of the type IB and IC EEL exhibited partial sequence similarity to HopPsyA. Effector activity of HopPsyB was indicated by the HR elicited in tobacco leaves by $E$. coli strains expressing this locus and the $P$. syringae pv. syringae 61 TTSS. Translocation of HopPsyB into host cells was demonstrated using 'AvrRpt 2 fusions. Consistent with the observed sequence polymorphisms, the effector activity of HopPsyB was distinct from HopPsyA, as different indicator plants responded to strains expressing these effectors. Most significantly, expression of HopPsyB affected the virulence of $P$. syringae pv. tomato DC3000 in several hosts. Other candidate effectors likely to have activities distinct from their homolog due to divergent sequence include $P$. syringae pv. syringae W4N15 HopPsyC2, P. syringae pv. syringae DH015 HopPsyG, and $P$. syringae pv. syringae $\mathrm{B} 452 \mathrm{HopPsyV}$. The $P$. syringae pv. persicae 5846 HopPtoB5 allele lacked the carboxy terminal 138 aa. Some effectors have been shown previously to be tolerant of carboxy terminal alterations without apparent alteration of function (Gopalan et al. 1996; Mudgett and Staskawicz 1999) but others, such as avrPphE, exhibit a change in activity upon single point mutation or $\mathrm{C}$ terminal extension (Stevens et al. 1998). Since indicator plants for the aforementioned effectors have not been established, it was not possible to determine at this time the phenotype of the candidate effectors.

The EEL of the characterized $P$. syringae strains appear to have assembled from transposed gene cassettes. Several gene cassettes were identified in the EEL of these strains that were conserved within or between EEL families, or both. A hopPsyC1$h o p P s y E$ cassette with conserved flanking, coding, and intergenic sequences was detected in Family III and IV EEL. Likewise, an eelF-eelG cassette was detected in Family IV, V, and VI EEL, and a vestige was present in Family II EEL. A third cassette was apparent in the strains carrying Family I EEL. The 
shcA-hopPsyA cassette found in the type IA EEL appears to be an inverted and truncated derivative of the $s h c B-h o p P s y B$ cassette found in the type IB and IC EEL (or vice versa). It is then likely that the loci for type II EEL AvrPphE8 allele, the Family V HopPtoB alleles, and the type VI HopPsyG gene could also represent gene cassettes. Thus, as indicated by the divergent percent GC of identified genes, each EEL appears to have a mosaic structure formed by horizontally acquired gene cassettes assembled in different combinations.

In nine out of the ten types of EEL identified in this study, a gene cassette encoding one or more effectors was expressed as part of the $h r p K$ operon. Since HrpK also appears to be se-

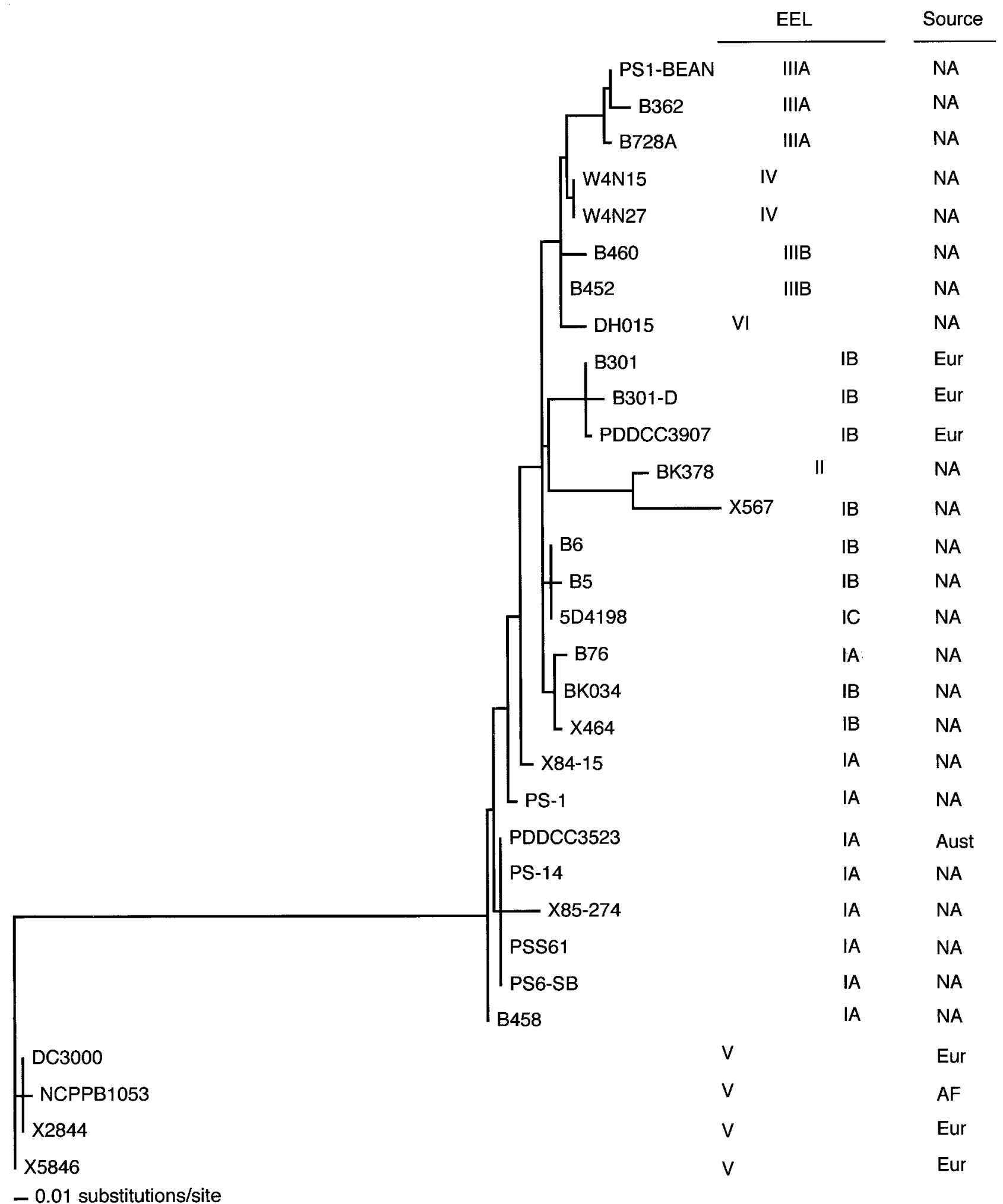

Fig. 5. Relationship between $h r p K$ alleles. The partial $h r p K$ coding sequences obtained during characterization of the exchangeable effector loci (EEL) were subjected to minimum evolution and maximum likelihood analysis using PAUP*4.0 after alignment by ClustalW. Sixty-nine of the 231 nt utilized were parsimony informative. Substitutions per site are indicated by the bar. Bootstrap analyses are shown in parentheses. The type of EEL carried by each strain and the geographical source for the strain is indicated on the right. NA = North America; Eur = Europe; Aust = Australia; and AF = Africa. 
creted by the hrp TTSS (J. Alfano, personal communication), it was possible that $h r p K$ could be a previously unrecognized component of the EEL. Four arguments, however, can be made against this conclusion. First, HrpK is essential to the activity of the hrp TTSS. Insertional inactivation or deletion of hrpK results in an $\mathrm{Hrp}^{-}$phenotype (Huang et al. 1991). Second, consistent with an essential function for HrpK and inclusion in the $h r p$ CCR, the genetic location of $h r p K$ is conserved in all hrp PAI characterized to date, whereas the location of gene cassettes carrying effectors, such as alleles of $a v r P p h E$ (Jackson et al. 1999; Stevens et al. 1998), appears to be variable. Third, the percent GC of $h r p K$ is very similar to that of the hrp PAI and is substantially higher than most EEL genes. Finally, sequence polymorphisms in $h r p K$ only weakly correlated with the adjacent gene cluster, and the correlations observed, in most cases, lacked strong bootstrap support. The only exceptions were the $h r p K$ alleles associated with the Family V EEL. Since these strains had been isolated or derived from European or North African sites, this clustering could be due to the geographical isolation of the strains. Although the limitations of the small sample size can not be fully excluded, the inability to link sequence polymorphisms in $h r p K$ with the adjacent gene cassette is consistent with an independent evolution for the EEL and $h r p K$.

The mosaic structure of characterized EEL is suggestive of an integron-like assembly of the EEL from transposed gene cassettes. Integrons were first identified during studies of the localized and sequential accumulation of promoterless antibiotic resistance genes in enteric bacteria but have since been found in many taxonomic groups of bacteria (Hall and Collis 1995). Integrons assemble through the activity of a transacting, site-specific integrase that mediates the insertion of transposed gene cassettes through homologous recombination of att sites (Grainge and Jayaram 1999). An imperfect inverted repeat is a key feature of the att site (Grainge and Jayaram 1999; Hall and Collis 1995) and is retained after the transposition event. Many transposed pathogenicity islands of bacteria are associated with a tRNA locus that carries inverted repeats (Hacker and Kaper 1999). Transposition of the LEE pathogenicity island in REPEC strains of $E$. coli has been linked to the activities of a tRNA gene-linked integrase (Tauschek et al. 2002), and tRNA-linked excision of virulence factors has been detected in other E. coli strains (Blum et al. 1994).
Adjacent to the EEL of $P$. syringae strains is a tRNA $A_{\text {leu }}$ locus (Alfano et al. 2000) that could function as the predicted att site, but analysis of the region flanking the EEL revealed that, with the exception of Family III and IC EEL, a 62-bp region $3^{\prime}$ to the tRNA gene was conserved between most types of EEL. If recombination occurred within the tRNA gene, little sequence conservation would be expected in this region. Within this conserved $3^{\prime}$ region, however, is an inverted repeat. A survey of the $P$. syringae pv. tomato DC3000 genome revealed at least two apparently functional homologs of a tRNA-linked integrase (S. W. Hutcheson, unpublished data) that could mediate excision and transposition of gene cassettes. tRNA-dependent excision of avr genes, an activity indicative of integrase activity (Hall and Collis 1995), has been observed in P. syringae strains (Jackson et al. 2000). When taken together, the mosaic structure of the EEL, the association of the EEL with a candidate att site, the presence of tRNA gene-associated integrases in the genome of at least one $P$. syringae strain, and the apparent integrase-dependent excision of an $a v r$ gene cassette argue in favor of an integron-like assembly of the EEL.

All of the EEL characterized in this study exhibited at least some similarity to a previously characterized EEL, and the majority of EEL were related to the EEL of $P$. syringae pv. syringae 61 . The similarity of these newly characterized EEL to previously characterized EEL could be due to an experimental bias resulting from the PCR amplification strategy and the strains surveyed. Although sequences obtained from P. syringae pv. syringae, P. syringae pv. phaseolicola, and P. syringae pv. tomato strains of North American and European origin were used in the initial primer design, some strains may simply be too divergent to be able to amplify the EEL using these primers. This could explain why the strategy predominately worked on $P$. syringae pv. syringae strains. A modified screen employing primers specific to conserved regions of queA and hrpL, however, did not reveal any additional types of EEL in some of the $P$. syringae strains with previously unamplifiable EEL. Due to the design of the primers, only the EEL linked with $h r p K$ were amplified in the initial screen. It may be that the PAI of the other strains are not inserted near queA. Another bias in the screen was the choice of strains surveyed. The majority of the $P$. syringae strains tested were $P$. syringae pv. syringae strains that had been iso-

Table 2. Ectopic expression of HopPsyB alters the plant response phenotypes of E. coli and Pseudomonas syringae transformants

\begin{tabular}{|c|c|c|c|c|c|c|c|c|}
\hline \multirow[b]{3}{*}{ Bacterium } & \multirow[b]{3}{*}{ Expressed effector } & \multicolumn{7}{|c|}{ Response observed in } \\
\hline & & \multirow[b]{2}{*}{ Tobacco $^{a}$} & \multicolumn{2}{|c|}{ A. thaliana $a^{a}$} & \multicolumn{4}{|c|}{${\text { B. } \text { oleracea }^{\mathrm{b}}}^{\mathrm{b}}$} \\
\hline & & & $R$ & $r$ & Brus. & Cab & Kale & Kohl. \\
\hline \multirow[t]{3}{*}{ E. coli $^{\mathrm{c}}$} & None & $\mathrm{N}$ & $\mathrm{N}$ & & & & & \\
\hline & HopPsyA & HR & $\mathrm{N}$ & $\mathrm{N}$ & $\mathrm{N}$ & $\mathrm{N}$ & $\mathrm{N}$ & \\
\hline & HopPsyB1 & HR & $\mathrm{N}$ & $\mathrm{N}$ & $\mathrm{N}$ & $\mathrm{N}$ & $\mathrm{N}$ & \\
\hline \multirow[t]{5}{*}{ P. syringae ${ }^{\mathrm{d}}$} & None & HR & $\mathrm{D}$ & $\mathrm{D}$ & $2.7 \pm 0.4$ & $4.2 \pm 0.2$ & $3.5 \pm 0.1$ & $4.4 \pm 0.3$ \\
\hline & HopPsyA & & $\mathrm{D}$ & & $1.8 \pm 0.3$ & $2.2 \pm 1.7$ & $2.6 \pm 1.5$ & $2.6 \pm 0.4$ \\
\hline & HopPsyB1 & & $\mathrm{D}$ & & $4.5 \pm 0.9$ & $3.6 \pm 0.2$ & $4.9 \pm 0.4$ & $4.9 \pm 0.4$ \\
\hline & 'AvrRpt2 & & $\mathrm{D}$ & $\mathrm{D}$ & & & & \\
\hline & HopPsyB1': 'AvrRpt2 & & HR & $\mathrm{D}$ & & & & \\
\hline
\end{tabular}

${ }^{\mathrm{a}}$ The plants were infiltrated with the indicated bacterial suspension and scored for plant responses at 16, 48, 72 and $96 \mathrm{~h}$. N, Null response; HR, necrotic reaction observed at $18 \mathrm{~h}$; D, expanding lesion observed by $72 \mathrm{~h}$. Blank cells, Not tested R, A. thaliana ecotype Columbia (RPS2 ${ }^{+}$); r, rps 2 derivative.

${ }^{\mathrm{b}}$ Response described as above or log population growth in diseased tissue after $48 \mathrm{~h}$. Populations were estimated by plate counts as described in the Materials and Methods and the mean \pm standard error of three replicates are shown. The experiments were repeated three times with similar results. Abbreviations: Brus., Brussel Sprouts cv. Long Island; Cabb., Cabbage cv. Earliana; Kale, Kale cv. Dwarf Blue; Kohl., Kohlrabi cv. Early White Vienna No substantial differences in growth of the tested strains were detected in Cauliflower cv. Early White Hybrid, Broccoli cv. Green Goliath, or Cabbage cv. Early Jersey Wakefield. Less than one log of growth was detected in Broccoli Raab cv. Spring for any tested strain. P values for the comparison of the mean populations reported for DC3000 expressing HopPsyA and HopPsyB were: Brus., 0.05; Cabb, 0.24, Kale, 0.14; Kohl. 0.05.

${ }^{\mathrm{c}}$ E. coli MC4100 (pHIR11)(pYXL2B)(pDSK600) transformant (expresses HopPsyA) or E. coli MC4100 (pHIR11-2070)(pYXL2B) transformant carrying pSHB5EEL1-600 (expresses HopPsyB1).

${ }^{\mathrm{d}}$ P. syringae Pto-DC3000 transformant carrying pYX1L (expresses HopPsyA), pSHB5EEL1-600 (expresses HopPsyB), pJC'avrRpt2-600 (expresses 'AvrRpt2) or pJCB5EEL2-AR2 (HopPsyB':'AvrRpt2). 
lated from North American sites. Since a possible geographical linkage was detected among strains with similar EEL, it may be that $P$. syringae populations indigenous to geographical regions not included in this study will have novel types of EEL. Thus, examination of the EEL from other geographical regions is a high priority. The size of the EEL also influences the ability to amplify the region. Although several long-range PCR protocols were employed to circumvent the difficulties of amplifying longer fragments, smaller fragments such as Family I EEL are simply easier to amplify and, thus, more likely to have been detected in these studies. Alternatively, the mechanism by which the EEL assembles could limit what genes transpose into this locus. Only genes associated with an att site would be able to insert into this site if the integron model is correct. Fusion of these gene cassettes to the hrpK operon would place expression of these genes under control of HrpL, as observed for most other effector genes (Fouts et al. 2002; Xiao and Hutcheson 1994), and would provide a direct means to coordinate expression of the effector with expression of the TTSS.

In summary, this partial survey of the EEL of $P$. syringae strains suggests that the EEL is a semiconserved site for TTSS-dependent effectors and provides a starting point for identification of the effectors produced by previously uncharacterized strains. Alterations in genetic composition of the EEL coupled with the sequence divergence detected among homologs of known effectors likely contribute to the genetic diversity of strains. Many of the effectors identified exhibited sequence divergence at the amino acid level from previously characterized homologs that likely affected their activity, as described above. The apparent insertion of transposed gene cassettes into the hrp PAI would add new effectors to the strain's genome if acquired by horizontal transfer and could explain, in part, the putative geographical correlations observed. Several strains had large deletions within the EEL that abolished expression of one or more effectors. The inversion of a cassette, like what apparently occurred in Family I EEL, could affect the level of expression by altering which promoter controls expression. Overall, these results suggest that the genetic diversity detected in the EEL can be attributed in part to i) acquisition of effector gene cassettes via horizontal transfer and integron-like assembly into the PAI, ii) accumulation of point mutations in the effector genes, and iii) genetic rearrangements such as gene duplications, deletions, insertion of IS elements, and inversion.

\section{MATERIALS AND METHODS}

\section{Bacterial strains.}

$P$. syringae and E. coli strains were grown in King's medium $\mathrm{B}$ media at $25^{\circ} \mathrm{C}$ and $37^{\circ} \mathrm{C}$, respectively. Rifampin $(200 \mu \mathrm{g}$ per $\mathrm{ml})$ and spectinomycin $(100 \mu \mathrm{g}$ per $\mathrm{ml})$ were added to the media, as indicated. Previously described strains, plasmids, and primers used in amplifications are described in Table 3.

Table 3. Other strains used in these studies, plasmids, and primers

\begin{tabular}{|c|c|c|}
\hline Strain, plasmid, or primer & Relevant properties & Source or reference \\
\hline \multicolumn{3}{|l|}{ Pseudomonas syringae strains } \\
\hline DC3000 & $\begin{array}{l}\text { Tomato/Arabidopsis pathogen; } \operatorname{Rif}^{\mathrm{r}} \text { derivative of NCBPP } 1106 \text { isolated in the U. K.; carries a } \\
\text { Type VA EEL }\end{array}$ & Cuppels 1986 \\
\hline Psy-61 & Weak bean pathogen; carries a Type IA EEL & Baker et al. 1987 \\
\hline B728a & Bean pathogen; carries a Type IIIA EEL & Hirano et al. 1999 \\
\hline $1032 \mathrm{~A}$ & Bean pathogen; carries a Type II EEL & Mansfield et al. 1994 \\
\hline \multicolumn{3}{|l|}{ Escherichia coli strains } \\
\hline DH5 $\alpha$ & $\left(\mathrm{r}_{\mathrm{k}}{ }^{-} \mathrm{m}_{\mathrm{k}}{ }^{-}\right)$recAl relA1 $\Delta(\arg F-l a c Z Y A) \mathrm{U} 169 \phi 80 \mathrm{~d} l a c Z D M 15$ & Invitrogen \\
\hline MC4100 & $\mathrm{F}^{1} \Delta(\arg F-l a c Z Y A) \mathrm{U} 169$ & Casadaban 1976 \\
\hline \multicolumn{3}{|l|}{ Plasmids } \\
\hline pDSK519 & incQ, $\mathrm{Kn}^{\mathrm{r}}$ & Keen et al. 1988 \\
\hline pDSK600 & incQ, $\mathrm{Sp}^{\mathrm{r}}$, triple lacUV5 promoter, mcs & Murillo et al. 1994 \\
\hline pHIR11 & hrp PAI from Psy-61 cloned into pLAFR3 & Huang et al. 1988 \\
\hline PHIR11-2070 & pHIR11 derivative carrying a hopPsyA::TnphoA insertion & Huang et al. 1991 \\
\hline pJC'avrRpt2-600 & $\begin{array}{l}\text { 617-bp EcoR1-HindIII fragment carrying C terminal effector domain of avrRpt2 ligated into } \\
\text { pDSK600 }\end{array}$ & This report \\
\hline pJCB5EEL2-AR2 & $\begin{array}{l}\text { 259-bp XbaI-HindIII fragment carrying hopPsyB RBS and N terminal } 86 \text { codons ligated into } \\
\text { pDSK519 }\end{array}$ & This report \\
\hline pLAFR3 & incP-1 $\mathrm{Tc}^{\mathrm{r}}$ cosmid vector & Staskawicz et al. 1987 \\
\hline pSHB5EEL1-600 & The $3.5-\mathrm{kb}$ EEL from $P$. syringae $\mathrm{B} 5$ cloned as an $X b a \mathrm{I}-E c o \mathrm{R} 1$ fragment into pDSK600 & This report \\
\hline pYX1L & The shcB-hopPsyA operon clones as a BamH1-EcoR1 fragment in pLAFR3 & Pirhonen et al. 1996 \\
\hline pYXL2B & Expresses the $h r p L$ locus from vector promoter & Xiao et al. 1994 \\
\hline \multicolumn{3}{|c|}{ 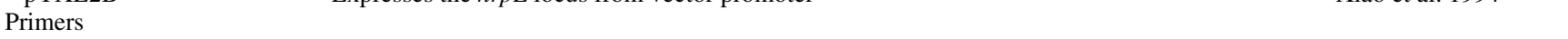 } \\
\hline $\mathrm{K} 2688$ & CTGGGCGGACAGATGATC & This report \\
\hline Q920 & AACGCCGAAACCAGCATCAA & This report \\
\hline D1F & GCAGAGTCAGGGTCATCAG & This report \\
\hline $\mathrm{D} 2 \mathrm{R}$ & TTCCAGCACAGCATCCAGTT & This report \\
\hline $\mathrm{D} 2 \mathrm{~F} /$ & GGTGCGGTAAGTGTCAGAAA & This report \\
\hline D3R & CGGTGTGGTGGTCATTGTC & This report \\
\hline $\mathrm{D} 3 \mathrm{~F}$ & TCATTGGCACTTCGCTACCT & This report \\
\hline B1F & CGATGTGGGTGAGCCTAATG & This report \\
\hline BER & GGAGCGGGATTCAGGATGT & This report \\
\hline $\mathrm{BEF}$ & GTGGTCGCTATCGGCAAGAA & This report \\
\hline $\mathrm{B} 5 \mathrm{~F}$ & TACTTTCAGCATTAGGCAACG & This report \\
\hline $\mathrm{B} 5 \mathrm{R}$ & GTCTGCCCTCGCCACGCTGTA & This report \\
\hline B5EEL1950-X & GCTCTAGAGCTGTATATCGGCTTTA & This report \\
\hline B5EEL1565-RI & CGGAATTCCGCGCGCTTGTCATTCAGTA & This report \\
\hline avrRpt2-412-RI & CGGAATTCCACGAGACGGGCGGTTCAAG & This report \\
\hline avrRpt2-1028-H & CCCAAGCTTTAGGGACCAAAAAGCCAGAC & This report \\
\hline P197-R1 & CCGGAATTCGGACGGTCTATATAAGGAGG & This report \\
\hline PB5ORF1-XbaI & GCTCTAGACAGTTCGGGATTGACAGG & This report \\
\hline
\end{tabular}




\section{Amplification of the EEL by PCR.}

Colony PCR reactions employed a Hybaid PCR Sprint thermocycler using a 10-min extension time and either Proofsprinter (Hybaid, Teddington, Middlesex, U.K.) or ProofPro (Continental Lab Products, San Diego, CA, U.S.A.) DNA polymerase enzyme mixtures. Primers K2688 and Q920 were chosen based on their ability to amplify previously characterized EEL in $P$. syringae pv. syringae 61, P. syringae pv. syringae $\mathrm{B} 728 \mathrm{a}$, and $P$. syringae pv. tomato $\mathrm{DC} 3000$. All other variables were set according to standard protocol or manufacturer's instructions for long-range PCR. PCR products were gel-purified and extracted using the Bio-Rad Prep-A-Gene Master Kit (Hercules, CA, U.S.A.) prior to sequencing. DNA was sequenced at the University of Maryland Biotechnology Institute using an ABI Model 3100 Automated Sequencer.

\section{Diagnostic PCR to determine conservation of $P$. syringae pv. tomato DC3000- and B728s-like EEL.}

Published sequences of $P$. syringae pv. tomato DC3000 and P. syringae pv. syringae $\mathrm{B} 728 \mathrm{a}$ were used to create primers internal to selected ORFs. Primers were then paired appropriately and utilized in Taq polymerase-based (Invitrogen, San Diego, CA, U.S.A.) PCR amplification, using a 5-min. extension time. For the P. syringae pv. syringae B728a-like EEL, the following primer sets were used: hopPsyCl-hopPsyE1 B1F, BER; hopPsyEl-hopPsyVl BEF, B5R; and hopPsyVl-queA B5F, Q920. For the $P$. syringae pv. tomato DC3000-like EEL, the following primer sets were used: hopPtoB-eelH D1F, D2R; eelH-eelF1 D2F, D3R; and eelF1-queA D3F, Q920.

\section{Construction of a $P$. syringae pv. syringae B5 EEL clone.}

The EEL was amplified from P. syringae pv. syringae B5, using tailed primers P197-R1 and PB5ORF1-Xba. After PCR, the fragment was digested with $X b a \mathrm{I}$ and $E c o \mathrm{RI}$ and was gel-purified using the Bio-Rad Prep-A-Gene Master Kit. The resulting fragment was ligated into XbaI-EcoRI-digested pDSK600 and was transformed into electrocompetent E. coli DH5 $\alpha$ cells. Plasmids were isolated from spectinomycin-resistant colonies and inserts were confirmed by PCR and sequencing.

\section{Construction of 'avrRpt2 fusions}

to $P$. syringae pv. syringae B5 ORF 2.

A 259-nt fragment carrying the $5^{\prime}$ portion of hopPsyBl (includes the native RBS and first 86 codons) was amplified by PCR from strain $P$. syringae pv. syringae $\mathrm{B} 5$ using primers B5EEL1950-X and B5EEL1565-RI. A 528-nt fragment carrying the C- terminal 176 codons for avrRpt 2 was amplified using tailed primers avrRpt2-412-R1 and avrRpt2-1028-H. Both fragments were gel-purified using the Bio-Rad Prep-A-Gene Master Kit, were digested with EcoRI, and were ligated. The desired fusion was amplified from the ligation mixture, using primers B5EEL1950-X and avrRpt2-1028-H, gel-purified as described above, and ligated into pDSK519 as an XbaI, HindIII fragment to create pJCB5EEL2-AR2.

\section{Plant assays.}

For pathogenicity trials, overnight cultures grown at $25^{\circ} \mathrm{C}$ were diluted to an optical density at $600 \mathrm{~nm}$ of 0.1 , diluted $10^{3}$ fold into water and infiltrated into leaves of the indicated plants. Plant responses were scored daily, and bacterial populations were monitored using the leaf disk assay of Bertoni and Mills (Bertoni and Mills 1987). For assessment of the ability to elicit the HR, overnight cultures were harvested, were washed in water, and were resuspended to $10^{8} \mathrm{CFU} / \mathrm{ml}$ for $P$. syringae pv. tomato DC3000 derivatives and $10^{9} \mathrm{CFU} / \mathrm{ml}$ for MC4100 derivatives. Leaf tissue was inoculated using a syringe and was scored for responses at $24 \mathrm{~h}$.

\section{Phylogenetic analyses.}

Sequences were aligned using ClustalW and an initial tree generated using minimum evolution and HKY85 distances in PAUP*4.0. Parameters were estimated using maximum likelihood and the GTR $+\mathrm{I}+\Gamma$ model. These estimated parameters were used to perform a minimum evolution search. The parameter estimation was then repeated, and the maximum likelihood-minimum evolution search was completed using the revised parameters. Bootstrapping was performed with 100 replicates.

\section{ACKNOWLEDGMENTS}

This work was supported by grants MCB 9729524 and MCB 0215417 from the National Science Foundation and by grants to J. Charity and K. Pak from the Howard Hughes Medical Institute Undergraduate Biological Sciences Education Program. We thank L. Losada, K. Ryan, and M. Roussis for their help with the PCR screens. The rps 2 A. thaliana was obtained from B. Staskawicz, University of California-Berkeley.

\section{NOTE ADDED IN PROOF}

Similar findings are being reported by Deng, W. L., Rehm, A., Charkowski, A., Rojas, C. M., and Collmer, A. Pseudomonas syringae exchangeable effector loci: Sequence diversity in representative pathovars and virulence function in $P$. syringae pv. syringae B728a. J. Bacteriol. In press.

\section{LITERATURE CITED}

Alfano, J. R., and Collmer, A. 1997. The type III ( $h r p)$ secretion pathway of plant pathogenic bacteria: Trafficking harpins, avr proteins and death. J. Bacteriol. 179:5655-5662.

Alfano, J. R., Kim, H.-S., Delaney, T. P., and Collmer, A. 1997. Evidence that the Pseudomonas syringae pv. syringae hrp-linked hrmA gene encodes an Avr-like protein that acts in an hrp-dependent manner within tobacco cells. Mol. Plant-Microbe Interact. 10:580-588.

Alfano, J. R., Charkowski, A. O., Deng, W.-L., Badel, J. L., PetnickiOcweija, T., van Dijk, K., and Collmer, A. 2000. The Pseudomonas syringae Hrp pathogenicity island has a tripartite mosaic structure composed of a cluster of type III secretion genes bound by exchangeable effector and conserved effector loci that contribute to parasitic fitness and pathogenicity in plants. Proc. Natl. Acad. Sci. U.S.A. 97:48564861 .

Baker, C. J., Atkinson, M. M., and Collmer, A. 1987. Concurrent loss in Tn5 mutants of the ability to induce the HR and host plasma membrane $\mathrm{K}^{+} / \mathrm{H}^{+}$exchange in tobacco. Phytopathol. 77:1268-1272.

Bertoni, G., and Mills, D. 1987. A simple method to monitor growth of bacterial populations in leaf tissue. Phytopathol. 77:832-835.

Blum, G., Ott, M., Lischewski, A., Ritter, A., Imrich, H., Tschape, H., and Hacker, J. 1994. Excision of large DNA regions termed pathogenicity islands from tRNA-specific loci in the chromosome of an Escherichia coli wild-type pathogen. Infect. Immun. 62:606-614.

Casadaban, M. J. 1976. Transposition and fusion of the lac genes to selected promoters in Escherichia coli using bacteriophage lambda and Mu. J. Mol. Biol. 104:541-555.

Chen, Z., Kloek, A. P., Boch, J., Katagiri, F., and Kunkel, B. N. 2000. The Pseudomonas syringae avrRpt 2 gene product promotes pathogen virulence from inside plant cells. Mol. Plant-Microbe Interact. 13:1312-1321.

Collmer, A., Lindegerg, M., Petnicki-Ocweija, T., Schneider, D., and Alfano, J. 2002. Genomic mining type III secretion system effectors in Pseudomonas syringae yields new picks for all TTSS prospectors. Trends Microbiol. 10:462-469.

Cuppels, D. A. 1986. Generation and characterization of Tn5 insertion mutations in Pseudomonas syringae pv. tomato. Appl. Environ. Microbiol. 51:323-327.

Dangl, J., and Jones, J. 2001. Plant pathogens and integrated defence responses to infection. Nature (London) 411:826-833.

Denny, T., Gilmour, M., and Selander, R. 1988. Genetic diversity and relationships of two pathovars of Pseudomonas syringae. J. Gen. Microbiol. 134:1949-1960.

Fouts, D., Abramovitch, R., Alfano, J., Baldo, A., Buell, C., Cartinhour, S., Chatterjee, A., D’Ascenzo, M., Gwinn, M., Lazarowitz, S., Lin, N.C., Martin, G., Rehm, A., Schneider, D., vanDijk, K., Tang, X., and Collmer, A. 2002. Genomewide identification of Pseudomonas syrin- 
gae pv. tomato DC3000 promoters controlled by the HrpL alternative sigma factor. Proc. Natl. Acad. Sci. U.S.A. 99:2275-2280.

Gopalan, S., Bauer, D. W., Alfano, J. R., Loniello, A. O., He, S. Y., and Collmer, A. 1996. Expression of the Pseudomonas syringae avirulence protein AvrB in plant cells alleviates its dependence on the hypersensitive response and pathogenicity (Hrp) secretion system in eliciting genotype-specific hypersensitive cell death. Plant Cell 8:1095-1105.

Grainge, I., and Jayaram, M. 1999. The integrase family of recombinases: Organization and function of the active site. Mol. Microbiol. 33:449456.

Guttman, D. S., and Greenberg, J. T. 2001. Functional analysis of the type III effectors AvrRpt2 and AvrRpm1 of Pseudomonas syringae with the use of a single copy genomic integration system. Mol. PlantMicrobe Interact. 14:145-155.

Guttman, D., Vinatzer, B., Sarkar, S., Ranall, M., Kettler, G., and Greenberg, J. 2002. A functional screen for the type III secretome of the plant pathogen Pseudomonas syringae. Science 295:1722-1726.

Hacker, J., and Kaper, J. 1999. The concept of pathogenicity islands. Pages 1-11 in: Pathogenicity Islands and Other Mobile Virulence Elements. J. Kaper and J. Hacker, eds. American Society for Microbiology Press. Washington, D.C.

Hall, R., and Collis, C. 1995. Mobile gene cassettes and integrons: Capture and spread of genes by site-specific recombination. Mol. Microbiol. 15:593-600.

Heu, S., and Hutcheson, S. W. 1993. Nucleotide sequence and properties of the hrmA locus associated with the P. syringae pv. syringae $61 \mathrm{hrp}$ gene cluster. Mol. Plant-Microbe Interact. 6:553-564.

Hirano, S., Charkowski, A., Collmer, A., Willis, D., and Upper, C. 1999. Role of the Hrp type III protein secretion system in growth of Pseudomonas syringae pv. syringae B728a on host plants in the field. Proc. Natl. Acad. Sci. U.S.A. 96:9851-9856.

Huang, H. C., Schuurink, R., Denny, T. P., Atkinson, M. M., Baker, C. J., Yucel, I., Hutcheson, S. W., and Collmer, A. 1988. Molecular cloning of a Pseudomonas syringae pv. syringae gene cluster that enables Pseudomonas fluorescens to elicit the hypersensitive response in tobacco. J. Bacteriol. 170:4748-4756.

Huang, H. C., Hutcheson, S. W., and Collmer, A. 1991. Characterization of the hrp cluster from Pseudomonas syringae pv. syringae 61 and TnphoA tagging of exported or membrane-spanning Hrp proteins. Mol. Plant-Microbe Interact. 4:469-476.

Hutcheson, S. 2001. The molecular biology of hypersensitivity to plant pathogenic bacteria. J. Plant Pathol. 83:151-172.

Hutcheson, S. W. 1998. Currents concepts of active defense in plants. Annu. Rev. Phytopathol. 36:59-90.

Hutcheson, S. W. 1999. The hrp cluster of Pseudomonas syringae: A pathogenicity island encoding a type III protein translocation complex? Pages 309-329 in: Pathogenicity Islands and Other Mobile Virulence Elements. J. B. Kaper and J. Harker, eds. American Society of Microbiology. Washington, D.C.

Hutcheson, S., Bretz, J., Losada, L., Charity, J., and Sussan, T. Regulation and detection of effectors translocated by Pseudomonas syringae. In: Developments in Plant Pathology: Pseudomonas syringae Pathovars and Related Pathogens. 2nd ed. N. Iacobelis, ed.. Kluwer Academic Publishers. Dordrecht, The Netherlands. In press.

Jackson, R., Mansfield, J., Arnold, D., Sesma, A., Paynter, C., Murillo, J., Taylor, J., and Vivian, A. 2000. Excision from tRNA genes of a large chromosomal region, carrying $\operatorname{avrPphB}$, associated with race change in the bean pathogen, Pseudomonas syringae pv. phaseolicola. Mol. Microbiol. 38:186-197.

Jackson, R. W., Athanassopoulos, E., Tsiamis, G., Mansfield, J. W., Sema, A., Arnold, D. L., Gibbon, M. J., Murillo, J., Taylor, J. D., and Vivian, A. 1999. Identification of a pathogenicity island, which contains genes for virulence and avirulence, on a large native plasmid in the bean pathogen Pseudomonas syringae pv. phaseolicola. Proc. Natl. Acad. Sci. U.S.A. 96:10875-10880.

Keen, N., Tamaki, J., Kobayashi, D., and Trollinger, D. 1988. Improved broad host range plasmids for DNA cloning in gram negative bacteria. Gene 70:191-197.

Kim, J. F., Charkowski, A. O., Alfano, J. R., Collmer, A., and Beer, S. V. 1998. Sequences related to transposable elements and bacteriophages flank avirulence genes of Pseudomonas syringae. Mol. Plant-Microbe Interact. 11:1247-1252

Leach, J. E., and White, F. F. 1996. Bacterial avirulence genes. Annu. Rev. Phytopathol. 34:153-179.

Leister, R. T., Ausubel, F. M., and Katagiri, F. 1996. Molecular recognition of pathogen attack occurs inside of plant cells in plant disease re- sistance specified by the Arabidopsis genes RPS2 and RPM1. Proc. Natl. Acad. Sci. U.S.A. 93:3459-3464

Li, T.-H., Benson, S. A., and Hutcheson, S. W. 1992. Phenotypic expression of the Pseudomonas syringae pv. syringae $61 \mathrm{hrp} / \mathrm{hrm}$ gene cluster in Escherichia coli requires a functional porin. J. Bacteriol. 174:1742-1749.

Mansfield, J., Jenner, C., Hockenhull, R., Bennett, M. A., and Stewart, R. 1994. Characterization of avrPphE, a gene for cultivar-specific avirulence from Pseudomonas syringae pv. phaseolicola which is physically linked to $h r p Y$, a new hrp gene identified in the halo-blight bacterium. Mol. Plant-Microbe Interact. 7:726-739.

Mudgett, M. B., and Staskawicz, B. J. 1999. Characterization of the Pseudomonas syringae pv. tomato AvrRpt2 protein: Demonstration of secretion and processing during bacterial pathogenesis. Mol. Microbiol. 32:927-941.

Murillo, J., Shen, H., Gerhold, D., Sharma, A., Cooksey, D. A., and Keen, N. T. 1994. Characterization of pPT23B, the plasmid involved in syringolide production by Pseudomonas syringae pv. tomato PT23. Plasmid 31:275-287.

Petnicki-Ocweija, T., Schneider, D., Tam, V., Chancey, S., Shan, L., Jamir, Y., Schechter, L., Janes, M., Buell, C., Tang, X., Collmer, A., and Alfano, J. 2002. Genomewide identification of proteins secreted by the Hrp type III protein secretion system of Pseudomonas syringae pv. tomato DC3000. Proc. Natl. Acad. Sci. U.S.A. 99:7652-7657.

Pirhonen, M. U., Lidell, M. C., Rowley, D., Lee, S. W., Silverstone, S., Liang, Y., Keen, N. T., and Hutcheson, S. W. 1996. Phenotypic expression of Pseudomonas syringae avr genes in E. coli is linked to the activities of the hrp-encoded secretion system. Mol. Plant-Microbe Interact. 9:252-260.

Reuter, K., Slany, R., Ullrich, F., and Kersten, H. 1991. Structure and organization of Escherichia coli genes involved in biosynthesis of the deazaguanine derivative of quenine, a nutrient factor for eukaryotes. J. Bacteriol. 173:2256-2264.

Staskawicz, B. J., Dahlbeck, D., and Keen, N. T. 1984. Cloned avirulence gene of Pseudomonas syringae pv. glycinea determines race-specific incompatibility on Glycine $\max$ (L.) Merr. Proc. Natl. Acad. Sci. U.S.A. 81:6024-6028.

Staskawicz, B. J., Dahlbeck, D., Keen, N., and Napoli, C. 1987. Molecular characterization of cloned avirulence genes from race 0 and 1 of Pseudomonas syringae pv. glycinea. J. Bacteriol. 169:5789-5794.

Stevens, C., Bennett, M., Athanossopoulos, E., Tsiamis, G., Taylor, J., and Mansfield, J. 1998. Sequence variations in alleles of the avirulence gene avrPphE.R2 from Pseudomonas syringae pv. phaseolicola lead to loss of recognition of the AvrPphE protein within bean cells and a gain in cultivar-specific virulence. Mol. Microbiol. 29:165-177.

Tauschek, M., Strugnell, R., and Robins-Browne, R. 2002. Characterization and evidence of mobilization of the LEE pathogenicity island of rabbit-specific strains of enteropathogenic Escherichia coli. Mol. Microbiol. 44:1533-1550.

van Dijk, K., Fouts, D. E., Rehm, A. H., Hill, A. R., Collmer, A., and Alfano, J. R. 1999. The Avr (effector) proteins HrmA (HopPsyA) and AvrPto are secreted in culture from Pseudomonas syringae pathovars via the Hrp (Type III) protein secretion system in a temperature and pH-sensitive manner. J. Bacteriol. 181:4790-4797.

van Dijk, K., Tam, V., Records, A., Petnicki-Ocweija, T., and Alfano, J. 2002. The ShcA protein is a molecular chaperone that assists in the secretion of the HopPsyA effector from the type III (Hrp) protein secretion system of Pseudomonas syringae. Mol. Microbiol. 44:1469-1481.

Vivian, A., and Gibbon, M. J. 1997. Avirulence genes in plant-pathogenic bacteria: Signals or weapons. Microbiol. 143:693-704.

Whalen, M. C., Innes, R. W., Bent, A. F., and Staskawicz, B. J. 1991 Identification of Pseudomonas syringae pathogens of Arabidopsis and a bacterial locus determining avirulence on both Arabidopsis and soybean. Plant Cell 3:49-59.

Xiao, Y., and Hutcheson, S. W. 1994. A single promoter sequence recognized by a newly identified alternate sigma factor directs expression of pathogenicity and host range determinants in Pseudomonas syringae. J. Bacteriol. 176:3089-3091.

Xiao, Y., Heu, S., Yi, J., Lu, Y., and Hutcheson, S. W. 1994. Identification of a putative alternate sigma factor and characterization of a multicomponent regulatory cascade controlling the expression of Pseudomonas syringae pv. syringae Pss61 hrp and hrmA genes. J. Bacteriol. 176:1025-1036.

Yuan, J., and He, S. Y. 1996. The Pseudomonas syringae Hrp regulation and secretion system controls the production and secretion of multiple extracellular proteins. J. Bacteriol. 178:6399-6402. 